\title{
Clinical and histopathological evaluation and habits associated with the onset of oral leukoplakia and erythroplakia
}

\author{
Avaliação clínica e histopatológica e hábitos associados \\ ao surgimento de leucoplasias e eritroplasias orais
}

Salomão Israel Monteiro Lourenço Queiroz; Ana Miryam Costa de Medeiros²; José Sandro Pereira da Silva33; Éricka Janine Dantas da Silveira ${ }^{4}$

\begin{abstract}
Objective: This research aims to establish the prevalence, factors associated with the onset, and clinical and histopathological features of oral leukoplakia and erythroplakia, so that these data can contribute to the prevention of these lesions and, consequently, of oral cancer. Material and method: A retrospective study was conducted at a reference service of Universidade Federal do Rio Grande do Norte (UFRN) from 2000 to 2012. To verify the association of variables, Pearson's chi-squared test and Fisher's exact test $(\phi \leq 0.05)$ were used. Results: Among 6,560 investigated records, 54 cases were selected, of which $44.4 \%$ were male and $55.6 \%$ female, with mean age of 56.93 years. Regarding habits, $72.2 \%$ were smokers and $25 \%$ were alcohol users; $17.9 \%$ showed association of both habits. Oral leukoplakia lesions were the most prevalent $(0.65 \%)$ and oral erythroplakia showed greater association with malignancy in the histopathological presentation $(\phi=0.001)$. Most lesions showed no symptoms $(\phi=0.004)$. The most frequent was oral leukoplakia in smoking women, with mean age of 57 years. Conclusion: Knowledge of associated factors and clinical characteristics of oral leukoplakia and erythroplakia is essential for establishing the correct diagnosis and treatment.
\end{abstract}

Key words: leukoplakia; erythroplakia; prevalence; habits; tobacco; alcoholism.

\section{INTRODUCTION}

The incidence of oral cancer has been increasing during the last decades in some countries, and it is the sixth death cause in the world, as approximately $50 \%$ of diagnosed patients die annually with this disease ${ }^{(25)}$. In Brazil, estimates for 2012 showed the occurrence of 14,170 new cases of cancer located in the oral cavity. In the Northeast region, there were 2,550 new cases: 1,640 in men, 910 in women ${ }^{(2)}$.

Around $80 \%$ of all oral cancers progress from potentially malignant lesions ${ }^{(16)}$. The squamous cell carcinoma is the most common type of oral cancer, representing more than $90 \%$ of the cases of malignant neoplasms in this region. It is generally diagnosed at advanced stages, what leads to high mortality and morbidity rates. Specialized treatment in the early phase is of the utmost importance to increase patients' chances of cure ${ }^{(17)}$.

Leukoplakia and erythroplakia are among the main potentially malignant lesions. The first is defined as a white patch or plaque that cannot be rubbed off, which cannot be clinically and histopathologically characterized as any other pathology. It is also the most frequent and the most studied one ${ }^{(14,20)}$. The second is defined as a red macule or plaque that cannot be clinically and histopathologically characterized as any other lesion. Despite being less frequent, it exhibits high potential for malignant transformation, and it may be associated with an adjacent leukoplakia, being then called oral erythroleukoplakia ${ }^{(14,20)}$.

First submission on 07/01/13; last submission on 07/01/14; accepted for publication on 07/01/14; published on 20/04/14

1. Master's student of Dentistry at the Post-Graduate Program in Public Health of Universidade Federal do Rio Grande do Norte (UFRN).

2. Doctorate in Oral Pathology from UFRN; senior associate professor at the Dentistry Department of UFRN.

3. Doctorate in Sciences from Universidade de São Paulo (USP); associate professor at the Dentistry Department of UFRN.

4. Doctorate in Oral Pathology from UFRN; associate professor at the Dentistry Department of UFRN. 
Researches have been undertaken to broaden the understanding of behavior and etiological factors of these lesions, which are little understood. Among them, smoking and/or drinking habits are the most evidenced in the literature, so that some studies have investigated the incidence and prevalence of these lesions in tobacco and alcohol users from diverse populations of the planet ${ }^{(1,3,5,7,8)}$. Solar radiation, diabetes, infections of the oral cavity and betel chewing are other associated factors cited as possible etiological agents. Sometimes these lesions are also attributed to idiopathic causes ${ }^{(1,14)}$.

It is important to analyze the prevalence and the clinical and histopathological characteristics of these oral lesions, as well as to verify their possible association with tobacco and/or alcohol use. The results of this study help define a strategy for preventing potentially malignant lesions, and, consequently, oral cancer, seen that clinical and histopathological comprehension of these lesions favor early diagnosis and the prescription of the correct treatment.

\section{METHOD}

This study was approved by the Research Ethics Committee of UFRN (report n ${ }^{0}$ 500/2011).

A retrospective cross-sectional study oral leukoplakia and erythroplakia cases was conducted at the service of oral diagnosis of Universidade Federal do Rio Grande do Norte (UFRN), using all archived medical records from January 2000 to June 2012.

The cases whose medical records contained all the necessary data for the conduction of the research were included in the sample; cases not confirmed by histopathological exam were excluded. The lesions presenting both clinical forms (erythroleukoplakias) were added to the erythroplakia group, because the malignant potential of this association is similar to that of erythroplakia ${ }^{(19)}$.

Data were collected a collection form, specially designed for the research, containing information about patients (name initials, medical record number, age, sex, color, dates of service, smoking and/or drinking habits) and about the lesion (clinical diagnosis, site, symptoms and histopathological diagnosis). Once the collection was performed, a data bank was built at Epi Info, where a statistical analysis was conducted, associated with chisquared test and Fisher's exact test. For all the tests, the significance level was $5 \%(p \leq 0.05)$.

\section{RESULTS}

A total of 6,560 medical records were investigated, 88 clinically identified cases, of which 54 were confirmed by histopathology
(43 leukoplakias and 11 erythroplakias), with prevalence rates of $0.65 \%$ and $0.16 \%$ for each lesion, respectively. The mean age of patients was 56.9 years (age ranging from 23 to 86 years); $44.4 \%$ were males and $55.65 \%$, females. Patients' most frequent skin colors were white and brown, representing, together, more than $80 \%$ of the cases (Table 1). As regards symptoms, 54.5\% of erythroplakias and $90.7 \%$ of leukoplakias were asymptomatic

\section{(Table 2).}

The most frequent lesion was leukoplakia, mostly affecting the lower lip mucosa followed by the buccal mucosa. In relation to histopathological diagnosis, erythroplakia cases presented greater association with the diagnosis of moderate and severe dysplasia. Leukoplakias were mostly in the stage of hyperkeratosis or mild epithelial dysplasia, and these associations were significant (Table 2).

In relation to the smoking habit, there was no statistically significant difference between the lesions, but $72.15 \%$ of the cases were tobacco users. As concerns the drinking habit, in more than $85 \%$ of the cases this datum was not confirmed (Table 1).

TABLE 1 - Socio-demographic features and habits associated with erythroplakia and leukoplakia cases from the service of oral diagnosis of UFRN (2000-2012)

\begin{tabular}{|c|c|c|c|c|c|}
\hline & \multicolumn{2}{|c|}{ Erythroplakia } & \multicolumn{2}{|c|}{ Leukoplakia } & \multirow{2}{*}{$p$} \\
\hline & $n$ & $\%$ & $n$ & $\%$ & \\
\hline \multicolumn{6}{|c|}{ Age } \\
\hline $0-49$ & 4 & 36.4 & 14 & 32.6 & \multirow{2}{*}{0.811} \\
\hline 50 or older & 7 & 63.6 & 29 & 67.4 & \\
\hline \multicolumn{6}{|c|}{ Sex } \\
\hline Male & 4 & 36.4 & 20 & 46.5 & \multirow[t]{2}{*}{0.546} \\
\hline Female & 7 & 63.6 & 23 & 53.5 & \\
\hline \multicolumn{6}{|c|}{ Color } \\
\hline White & 3 & 27.3 & 22 & 51.2 & \multirow{3}{*}{0.052} \\
\hline Brown & 5 & 45.5 & 19 & 44.2 & \\
\hline Black & 3 & 27.3 & 2 & 4.7 & \\
\hline \multicolumn{6}{|c|}{ Smoking habit } \\
\hline Yes & 9 & 81.8 & 30 & 69.8 & \multirow{2}{*}{0.426} \\
\hline No & 2 & 18.2 & 13 & 30.2 & \\
\hline \multicolumn{6}{|c|}{ Drinking habit } \\
\hline Yes & 3 & 27.3 & 4 & 9.3 & \multirow{2}{*}{0.113} \\
\hline Not informed & 8 & 72.7 & 39 & 90.7 & \\
\hline
\end{tabular}




\begin{tabular}{|c|c|c|c|c|c|}
\hline \multicolumn{6}{|c|}{$\begin{array}{l}\text { TABLE } 2 \text { - Clinical and histopathological features } \\
\text { of oral erythroplakia and leukoplakia cases at the } \\
\text { service of oral diagnosis of UFRN (2000-2012) }\end{array}$} \\
\hline & \multicolumn{2}{|c|}{ Erythroplakia } & \multicolumn{2}{|c|}{ Leukoplakia } & \multirow{2}{*}{$p$} \\
\hline & $n$ & $\%$ & $n$ & $\%$ & \\
\hline \multicolumn{6}{|c|}{ Lesion site } \\
\hline Floor of the mouth & 2 & 18.2 & 2 & 4.7 & \\
\hline Gingiva & 1 & 9.1 & 4 & 9.3 & \\
\hline Lower lip & 2 & 18.2 & 10 & 23.3 & \\
\hline Tongue & 3 & 27.3 & 2 & 4.7 & \\
\hline Buccal mucosa & 0 & 0 & 10 & 23.3 & 0.162 \\
\hline Hard palate & 1 & 9.1 & 8 & 18.6 & \\
\hline Soft palate & 1 & 9.1 & 2 & 4.7 & \\
\hline Alveolar ridge & 1 & 9.1 & 5 & 11.6 & \\
\hline \multicolumn{6}{|c|}{ Symptomatology } \\
\hline Symptomatic & 5 & 45.5 & 4 & 9.6 & 0.004 \\
\hline Asymptomatic & 6 & 54.5 & 39 & 90.7 & \\
\hline \multicolumn{6}{|c|}{ Degree of epithelial dysplasia } \\
\hline $\begin{array}{l}\text { Hyperkeratosis/mild } \\
\text { dysplasia }\end{array}$ & 3 & 27.3 & 37 & 86 & \\
\hline $\begin{array}{l}\text { Moderate/severe } \\
\text { dysplasia }\end{array}$ & 5 & 45.5 & 4 & 9.3 & 0.001 \\
\hline $\begin{array}{l}\text { Squamous cell } \\
\text { carcinoma }\end{array}$ & 3 & 27.3 & 2 & 4.7 & \\
\hline
\end{tabular}

\section{DISCUSSION}

The conduction of sectional studies is very important to understand the profile of a determined population affected by a group of lesions. In the case of potentially malignant lesions, this knowledge may help in planning public policies on diagnosis and conduct in patients at risk for this group of lesions, since they may precede the onset of oral cancer. Based on this fact, this study assessed all the cases of oral leukoplakia and erythroplakia, trying to characterize them clinically and histopathologically, and verifying the probable factors associated to their onset.

Leukoplakia is the most frequent and the most studied potentially malignant lesion. Erythroplakia, despite being less frequent, is also commonly studied, because of its high potential for malignant transformation ${ }^{(1,14,20)}$. Leukoplakia prevalence rates in studies on Thailand, in $2002^{(4)}$ and $2007^{(10)}$, were $1.7 \%$ and $1.8 \%$, respectively. In countries like Germany, Slovenia, and the United States, prevalence ranged from $0.9 \%$ to $6.2 \%(9,18,19)$. These relatively higher indices may be explained by the fact that a large part of the population presents the habit of smoking. In studies by Yang et al. ${ }^{(26)}$, in Taiwan, and by Pearson et al. ${ }^{(15)}$, in the population of Bangladesh and the United Kingdom, the prevalence indices of this lesion were even higher (24.4\% and 25\%), what is explained by the high levels of alcohol, tobacco and betel use.

In the present research leukoplakia was found in $0.65 \%$ of patients attended in the studied period, with values below those found in the cited populations, but possibly associated to tobacco consumption, as $69.8 \%$ of the cases were smokers. Erythroplakia had a prevalence of $0.16 \%$, and $81.8 \%$ of the cases were smokers, values similar to those found in studies by Hashibe et al. ${ }^{(6)}$, who verified a prevalence of $0.02 \%$ to $0.83 \%$ in Asian countries

Hosni et al. ${ }^{(8)}$ demonstrated that these potentially malignant lesions are more common in male patients, while Yang et al. ${ }^{(26)}$ verified higher incidence in females. As regards age, studies show higher frequency of middle-aged and elderly patients ${ }^{(8,18,19,26)}$.

In the present study, patients exhibited mean age of 56.9 years (age ranging from 23 to 86 years), what confirms the studies cited herein, probably because patients in this age group are more exposed to the habits of smoking and drinking. It was also possible to observe that females were more affected, with $55.6 \%$ of the cases, although predilection for a specific sex was not statistically significant for either lesion. This is in accordance with studies by Lapthanasupkul et al. ${ }^{(10)}$ that did not find significant difference between sexes, probably because the habits of smoking and drinking are becoming more and more common among women.

In this research, as in those by Ariyawardana et $a l^{(1)}$ and Harris et al..$^{(7)}$, more than $80 \%$ of the cases clinically diagnosed as leukoplakias presented a histological diagnosis of hyperkeratosis/ mild epithelial dysplasia, showing a less aggressive nature $(p=$ 0.001). Even so, the rate of leukoplakia malignant transformation has been assessed in several studies, and must be considered.

Lee et al. ${ }^{(11)}$ affirmed that $0.13 \%$ to $36.4 \%$ of all leukoplakias may suffer malignant transformation after a period ranging from one to 11 years. Pimenta et al. ${ }^{(16)}$ showed that $1 \%$ to $28 \%$ of the lesions presenting epithelial dysplasia progress to carcinoma. Liu et al ${ }^{\left({ }^{(12)}\right.}$ performed a retrospective analysis of 218 cases, evidencing that 39 (17.9\%) underwent malignant transformation, within an average period of 5.2 years.

In the research, leukoplakia had histopathological diagnosis of squamous cell carcinoma in $4.7 \%$ of the cases. This means that even if this lesion is represented in its majority by hyperkeratosis, a non aggressive lesion, it has to be assessed and conducted with caution and concern, since with its progression the possibility of malignant transformation is relatively high in comparison to other potentially malignant lesions. 
Some clinical features have been reported in association with the increased risk of malignant transformation in leukoplakias and erythroplakias: female gender, long lasting lesions that persist even after elimination of etiologic factors, lesions located on highrisk areas (floor of the mouth, lateral surface of the tongue), and non-homogeneous lesions with exophytic, papillary or verrucous $\operatorname{aspect}^{(22)}$.

According to Van Der Waal( ${ }^{(22)}$, although erythroplakia is less common than leukoplakia, it presents greater potential for malignant transformation, because around $90 \%$ of the cases are diagnosed as moderate or severe epithelial dysplasia. Similarly, Scully and Porter ${ }^{(21)}$ found a potential malignant transformation of erythroplakia that ranges from $75 \%$ to $90 \%$.

In the present study, erythroplakia developed in more than $72 \%$ of the cases diagnosed as moderate and severe epithelial dysplasia or squamous cell carcinoma ( $p=0.001$ ), showing the importance of attention when these lesions are present: their identification represents a warning about the possibility of oral cancer development. Thus, a red lesion of the mucosa must be a cause for worry if it is present in any of the high-risk areas for the development of cancer and persists for more than 14 days after the elimination of all etiological, biological, chemical and physical factors.

These lesions may be present in all the regions of the oral mucosa; however, there are places in which their occurrence is more or less common. This is due to the behavioral pattern of the patient regarding consumption of possible causative agents ${ }^{(10)}$. In this research there was preference for the mucosa of the lower lip followed by the buccal mucosa, which is the most affected site in some studies ${ }^{(0,10,25)}$.

Authors report that the two most common sites for malignant transformation would be the tongue and the floor of the mouth $^{(9,14)}$. In the cases herein assessed, five (9.3\%) lesions were histopathologically diagnosed as squamous cell carcinoma: one on the tongue, one on the palate, one on the lip and two on the floor of the mouth.

Despite the importance of early identification of these lesions, many times they go unnoticed to the dental surgeon, and frequently are handled in an inadequate form, probably for being, in general, asymptomatic. Because they represent potentially malignant lesions and may be clinically similar to other oral cavity diseases, a differential diagnosis is necessary with other white and red lesions such as: erythematous candidiasis, local irritation, mucositis, lichen planus, lupus erythematosus, drug reaction, median rhomboid glossitis, hairy leukoplakia, leukoedema, morsicatio buccarum, frictional keratosis, and nicotine stomatitis ${ }^{(6,14)}$. Differential diagnosis must be made criteriously.
In the present study, more than $83.3 \%$ of the cases did not present symptoms $(p=0.004)$, what increases the worry with these lesions, even when symptoms are not present.

The relationship between potentially malignant lesions in tobacco users and oral cancer is not clear: these lesions may happen in patients who never smoked. However, studies have observed significant average rates of malignant transformation of these lesions in smoking patients ${ }^{(13,24)}$. Van Der Waal ${ }^{(23)}$ states that such lesions are more common in smoking patients and that alcohol may be an independent risk factor, but further evidence is still needed. In relation to smoking, the present research showed that $72.2 \%$ of the patients were smokers, showing the possibility of this association. In relation to alcohol, data were not relevant, seen that in the majority of records analyzing this information was neglected, showing the necessity of a better assessment by the service regarding this habit. Even with this deficit in the variable analysis, association with smoking was found in $17.9 \%$ of the cases.

Before planning any type of intervention in these lesions, it is necessary to conduct a histopathological study, to exclude the possibility of malignancy and to determine whether there is dysplasia, as well as its degree, because treatment must be guided by the definitive diagnosis obtained by biopsy. Lesions that exhibit moderate and severe epithelial dysplasia or persist after elimination of the possible etiological agents must be completely excised.

\section{CONCLUSION}

The most frequent lesion was leukoplakia in smoking women, with mean age of 57 years. Clinically, most of the lesions were asymptomatic. Regarding the histopathological exam, erythroplakia was more associated with the most severe degrees of dysplasia.

The present study showed that the relationship of tobacco consumption with the development of the analyzed lesions is very similar to those reported in published works. Thus, it is prudent to worry about this habit, seen that it is already more evident in numerous populations of the planet that smokers present higher frequency of these potentially malignant lesions.

These lesions are, in their majority, asymptomatic, so, a criterious clinical exam conducted by the dental surgeon is of extreme importance in their early diagnosis. Because they present potential for malignant transformation, these lesions demand the conduction of biopsy: their histological pattern will partially determine prognosis, and, consequently, the dental surgeon's conduct in relation to them. 


\section{RESUMO}

Objetivo: Esta pesquisa objetiva estabelecer a prevalência, os fatores associados ao surgimento e as características clínicas e bistopatológicas das leucoplasias e eritroplasias orais, a fim de que estes dados possam contribuir na estratégia de prevenção ao desenvolvimento dessas lesões e, consequentemente, do câncer oral. Material e método: Foi realizado estudo retrospectivo em um serviço de referência da Universidade Federal do Rio Grande do Norte (UFRN) no perído de 2000 a 2012. Para verificar a associação das variáveis foi utilizado o teste qui-quadrado e o exato de Fisher ( $\mathrm{p} \leq 0,05)$. Resultados: Foram investigados 6.560 prontuários, tendo sido selecionados 54 casos, dos quais 44,4\% do sexo masculino e 55,6\% do feminino, com idade média de 56,93 anos. Com relação aos hábitos, 72,2\% eram fumantes e 25\% usuários de álcool, sendo que 17,9\% exibiam associação dos dois hábitos. As leucoplasias orais foram as lesões maisprevalentes (0,65\%), e as eritroplasias orais apresentaram maior associação com apresentação maligna no diagnóstico bistopatológico $(\mathrm{p}=0,001)$. A maioria das lesões não apresentou sintomatologia $(\mathrm{p}=0,004)$. A leucoplasia oral foi mais frequente em mulheres fumantes com média de idade de 57 anos. Conclusão: 0 conbecimento dos fatores associados e das características clinicas das eritroplasias e leucoplasias orais é essencial para 0 estabelecimento do correto diagnóstico e tratamento.

Unitermos: leucoplasia; eritroplasia; prevalência; hábitos; fumo; alcoolismo.

\section{REFERENCES}

1. ARIYAWARDANA, A. et al. Prevalence of oral cancer and pre-cancer and associated risk factors among tea estate workers in the central Sri Lanka. J Oral Pathol Med, v. 36, n. 10, p. 581-7, 2007.

2. BRASIL. Instituto Nacional de Câncer José Alencar Gomes da Silva. Coordenação Geral de Ações Estratégicas. Coordenação de Prevenção e Vigilância. Estimativa 2012: incidência de câncer no Brasil. Rio de Janeiro: INCA, 2012, p. 118.

3. CASTELlSagué, X. et al. The role of type of tobacco and type of alcoholic beverage in oral carcinogenesis. Int J Cancer, v. 108, n. 5 , p. 741-9, 2004.

4. DHANUTHAI, K.; DECHA, S.; ATORNKIDJAWAT, N. The study of lesions clinically diagnosed as leukoplakia in a group of Thai patients. J Dent Assoc Thai, v. 52, p. 399-406, 2002

5. FERNANDES, J. P.; BRANDÃO, V. S. G.; Lima, A. S. S. Prevalência de lesões cancerizáveis bucais em indivíduos portadores de alcoolismo. Rev Bras Cancerol, v. 54, n. 3, p. 239-44, 2008.

6. HASHIBE, M. et al. Chewing tobacco, alcohol, and the risk of erythroplakia. Cancer Epidemiol Biomarkers Prev, v. 9, n. 7, p. 639-45, 2000.

7. HARRIS, C. K. et al. Prevalence of oral mucosal lesions in alcohol misusers in South London.J Oral Pathol Med, v. 33, n. 5, p. 253-9, 2004.

8. HOSNI, E. S. et al. Oral erythroplakia and speckled leukoplakia: retrospective analysis of 13 cases. Braz J Otorbinolaryngol, v. 75, n. 2, p. 295-9, 2009.

9. KOVAC-KAVCIC, M.; SKALERIC, U. The prevalence of oral mucosal lesions in a population in Ljubljana, Slovenia.J Oral Pathol Med, v. 29, n. 7, p. 331-5, 2000.

10. LAPTHANASUPKUL, P.; POOMSAWAT, S.; PUNYASINGH, J. A clinicopathologic study of oral leukoplakia and erythroplakia in a Thai population. Quintessence Int, v. 38, n. 8, p. e448-55, 2007.
11. LEE, J. J. et al. Factors associated with underdiagnosis from incisional biopsy of oral leukoplakic lesions. Oral Surg Oral Med Oral Pathol Oral Radiol Endod, v. 104, n. 2, p. 217-25, 2007.

12. LIU, W. et al. Malignant transformation of oral leukoplakia: a retrospective cohort study of 218 Chinese patients. BMC Cancer, v. 10, p. $685,2010$.

13. MIRBORD, S. M.; AHING, S. I. Tobacco-associated lesions of the oral cavity: Part I. Nonmalignant lesions. J Can Dent Assoc, v. 66, n. 5 , p. 252-6, 2000.

14. NEVILLE, B. W. et al. Patologia epitelial. In: Neville, B.W. et al. Patologia oral e maxilofacial. Tradução: Danielle Resende Camisasca. 3. ed. Rio de Janeiro, RJ: Elsevier, 2009. Cap. 10, p. 363-453.

15. PEARSON, N. et al. Prevalence of oral lesions among a sample of Bangladeshi medical users aged 40 years and over living in Tower Hamlets, UK. Int Dent J, v. 51, n. 1, p. 30-4, 2001.

16. PIMENTA, F. J. et al. Molecular alterations in the tumor suppressor gene WWOX in oral leukoplakias. Oral Oncol, v. 44, n. 8 , p. 753-8, 2008.

17. PULTE, D.; BRENNER, H. Changes in survival in head and neck cancers in the late $20^{\text {th }}$ and early $21^{\text {st }}$ century: a period analysis. Oncologist, v. 15 , n. 9, p. 994-1001, 2010.

18. REICHART, P. A.; KOHN, H. Prevalence of oral leukoplakias in 1000 Berliners. Oral Dis, v. 2, n. 4, p. 291-294, 1996.

19. REICHART, P. A. Oral mucosal lesions in a cross-sectional study of aging Germans. Community Dent Oral Epidemiol, v. 28, n. 5, p. 390-8 2000

20. SILVEIRA, E. J. D. et al. Lesões orais com potencial de malignização: análise clínica e morfológica de 205 casos.J Bras Patol Med Lab, v. 45, n. 3, p. 233-8, 2009 .

21. SCULLY, C.; PORTER, S. ABC of oral health. Swellings and red, white, and pigmented lesions. BMJ, v. 321, n. 7255, p. 225-8, 2000. 
22. VAN DER WAAL I. Potentially malignant disorders of the oral and oropharyngeal mucosa; terminology, classification and present concepts of management. Oral Oncol, v. 45, n. 4/5, p. 317-23, 2009.

23. VAN DER WAAL, I. Potentially malignant disorders of the oral and oropharyngeal mucosa; present concepts of management. Oral Oncol, v. 46, n. 6, p. 423-5, 2010.
24. WALSH, P. M.; EPSTEIN, J. B. The oral effects of smokeless tobacco. J Can Dent Assoc, v. 66, n. 1, p. 22-5, 2000.

25. WARNAKULASURIYA, S. Global epidemiology of oral and oropharyngeal cancer. Oral Oncol, v. 45, n. 4-5, p. 309-16, 2009.

26. YANG, Y. H. et al. Epidemiological survey of oral submucous fibrosis and leucoplakia in aborigines of Taiwan. J Oral Pathol Med, v. 30, p. 213-9, 2001.

\section{MAILING ADDRESS}

Salomão Israel Monteiro Lourenço Queiroz

Universidade Federal do Rio Grande do Norte; Departamento de Odontologia; Av. Senador Salgado Filho, 1.757; Lagoa Nova; CEP: 59056-000; Natal-RN, Brazil; Phone: +55 (84) 9600-6633; e-mail: salomaoisrael10@gmail.com. 